\title{
REVIEW
}

\section{Burkitt's lymphoma: new insights into molecular pathogenesis}

\section{Bellan, S Lazzi, G De Falco, A Nyongo, A Giordano, L Leoncini}

J Clin Pathol 2003;56:188-193

The World Health Organisation classification reports three subcategories of Burkitt's lymphoma (BL)-endemic, non-endemic, and immunodeficiency associated-proposed to reflect the major clinical and genetic subtypes of this disease. These different types of BL have been reviewed and studied by immunohistochemistry and molecular methods. The results point out the heterogeneity of $B L$ and suggest that AIDS related $B L$ may have a different pathogenesis from that of classic BL.

See end of article for authors' affiliations

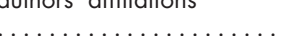

Correspondence to: Professor L Leoncini, Institute of Pathological

Anatomy and Histology, University of Siena, Nuovo Policlinico 'Le Scotte', Via delle Scotte, 6, 53100

Siena, Italy;

leoncinil@unisi.it

Accepted for publication 11 July 2002 n 1958, Dennis Burkitt first described a disorder associated with jaw tumours in African children. ${ }^{1}$ In 1961, the neoplasm was identified as a form of malignant lymphoma, and what had initially emerged as a clinical syndrome became a pathological entity called Burkitt's lymphoma (BL). ${ }^{2}$ Histologically, Burkitt's tumours are composed of monomorphic, medium sized cells with round nuclei, multiple nucleoli, and relatively abundant basophilic cytoplasm, which may give the cells a "cohesive appearance" (fig 1). These tumours have an extremely high rate of proliferation, in addition to a high rate of cell death (apoptosis). A "starry sky" pattern is usually present, imparted by numerous benign macrophages that have ingested apoptotic tumour cells. The cell of origin of BL is currently thought to be a germinal centre B cell, ${ }^{3}$ although several studies of IgHV genes in BLs suggest that they may derive from memory B cells rather than germinal centre B cells. ${ }^{4}$

\begin{abstract}
"Most AIDS related Burkitt's lymphomas in Western countries are Epstein-Barr virus (EBV) negative, whereas in Africa they are strongly associated with EBV"
\end{abstract}

BL occurs as an Epstein-Barr virus (EBV) associated malignancy among children in the malaria belt of equatorial Africa (endemic BL), ${ }^{5}$ and sporadically in other geographical areas, where it also occurs among adults (sporadic BL). ${ }^{67}$ The most common site of involvement of endemic BL is the kidneys. Jaw tumours are age related with an overall incidence in Uganda of 50\%. ${ }^{7}$ In contrast, the terminal ileum and lymph nodes are the more commonly involved sites in sporadic BL. ${ }^{8}{ }^{9} \mathrm{~A}$ common translocation $\mathrm{t}(8 ; 14)$ and the consequent c-myc rearrangement and overexpression have been identified in endemic and sporadic BL. However, some not very strict associations be- tween JH and DH recombination have been identified at 14q32, with distant 5' c-myc recombination in endemic cases of $\mathrm{BL}$, whereas in sporadic cases $S \mu$ and $S \alpha$ recombination was identified ${ }^{10}$ at $14 \mathrm{q} 32$, with near $5^{\prime}$ or intronic c-myc recombination at $8 \mathrm{q} 24$. These differences between endemic and sporadic BL do not mean that each of these subtypes of lymphoma represents a perfectly homogeneous entity. ${ }^{8}$ Instead, it seems probable that $\mathrm{BL}$ is composed of a mixture of molecular types and that the incidence of each subtype might depend upon environmental factors. ${ }^{81}$ Yet, the sporadic form of BL can also occur in endemic areas, ${ }^{12}$ as reported in table 1 , which summarises the distribution of BL collected from endemic areas of Kenya according to the age of patients, the clinical pathological characteristics, and the EBV and human immunodeficiency virus (HIV) status. These observations emphasise the importance of precise disease definition for biological and epidemiological studies. In particular, it is interesting that eight cases stand out from BL occurring in young adults as being HIV positive.

In fact, BL has frequently been reported as a common neoplasm in HIV infected patients, ${ }^{13}$ although it is not known why BL is so common in HIV and not in other forms of immunodepression. These lymphomas, which are now better listed as "AIDS related BL", ${ }^{14}$ usually display an activation of c-myc by chromosome translocations that show structural similarities to those found in patients with sporadic BL. ${ }^{15}$ Nonetheless, most AIDS related BLs in Western countries are EBV negative, ${ }^{15}$ whereas in Africa they are strongly associated with EBV. ${ }^{12}$

The term Burkitt-like (BL-like) lymphoma has been commonly applied to those tumours that have morphological features intermediate between large cell lymphoma with centroblastic or immunoblastic features and typical BL. The revised European-American lymphoma classification gives BL-like lymphoma provisional status, leaving the differential diagnosis between BL and diffuse large $B$ cell lymphoma (DLBCL) unresolved. ${ }^{16}$ The oncologists recommended that the category of BL-like lymphoma be reserved for tumours to be treated "like Burkitt lymphoma". A recent study by the southwest oncology group concluded that BL-like lymphoma can be recognised by its combined morphology and phenotypical features and that it represents a high

Abbreviations: BL, Burkitt's lymphoma; DLBCL, diffuse large $B$ cell lymphoma; EBV, Epstein-Barr virus; HIV, human immunodeficiency virus; $\mathrm{Rb}$, retinoblastoma; $\mathrm{WHO}$, World Health Organisation 


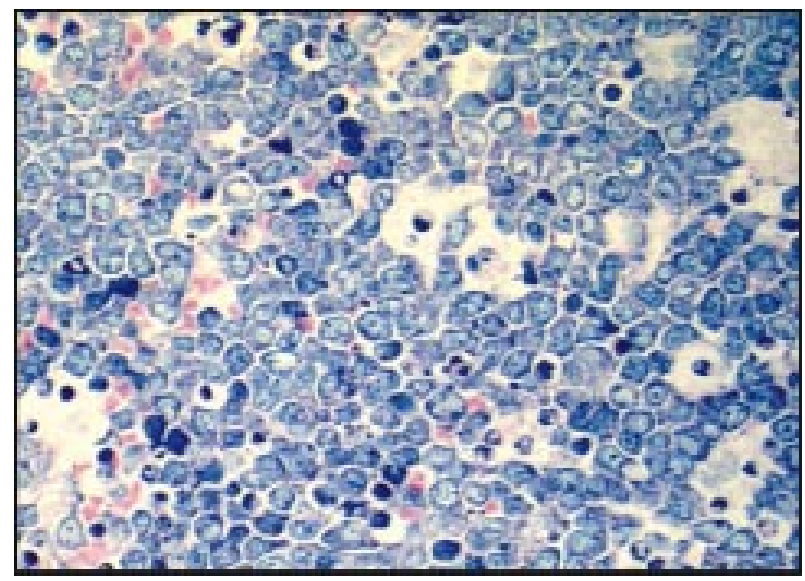

Figure 1 Typical morphological pattern of Burkitt's lymphoma (Giemsa stained; original magnification, $\times 375$ ).

grade lymphoma much closer to BL than DLBCL. ${ }^{17}$ In the World Health Organisation (WHO) classification, BL-like lymphoma is listed as a morphological variant of BL (atypical $\mathrm{BL})$, in addition to the three subcategories-endemic, sporadic, and immunodeficiency associated-proposed to reflect the major clinical and genetic subtypes of this disease.$^{14}$ In the WHO classification, the definition of atypical $\mathrm{BL}$ is a lymphoma that morphologically resembles BL, but has more pleiomorphism or larger cells than classic BL, and has a proliferation fraction of $>90 \%$. The necessary cytogenetics for the diagnosis of $\mathrm{BL}$ should be the presence of the $\mathrm{t}(8 ; 14)$ (q24; 32 ) translocation and its variants, or c-myc rearrangement. If cytogenetic or Southern blot cannot be applied to solid tumours the most reasonable surrogate for c-myc rearrangement is probably the proliferation fraction. Therefore, cases in which cytogenetic analysis is not available should not be diagnosed as BL or BL-like without a Ki-67 fraction close to $100 \%{ }^{14}$
Table 1 Distribution of BL collected from endemic areas according to the age of patients, the clinicopathological characteristics, and EBV and HIV status

\begin{tabular}{lll}
\hline & $\begin{array}{l}\text { BLage under 16 } \\
\text { years (range 2-16; } \\
\text { median 6) }\end{array}$ & $\begin{array}{l}\text { BL age over 16 years } \\
\text { (range, 17-58; median } \\
29)\end{array}$ \\
\hline $\begin{array}{ll}\text { Total cases } \\
\text { Male/Female }\end{array}$ & 23 & 16 \\
Site & $14 / 9$ & $10 / 6$ \\
$\quad$ Jaw & 16 & \\
Nodal & 3 & 2 \\
Ileum & 2 & 7 \\
Other & 2 & 5 \\
HIV & 0 & 2 \\
EBV & 21 & 8 \\
\hline
\end{tabular}

BL, Burkitt's lymphoma; EBV, Epstein-Barr virus; HIV, human immunodeficiency virus.

The morphological similarity between BLs probably results from the fact that they all have a common translocation, $\mathrm{t}(8 ; 14)$, and consequent c-myc rearrangement and overexpression. However, it is also true that BLs account for only $30 \%$ of lymphomas bearing a c-myc translocation at presentation. ${ }^{18}$ Furthermore, the c-myc translocation is not the only genetic lesion found in $\mathrm{BL}^{8}$ and myc transformed cells are usually characterised by the loss of expression of several genes. ${ }^{19}$ Cooperating alterations of cell cycle associated genes probably contribute to the pathogenesis of BL. ${ }^{820}$ p53 mutations have been found in $30-40 \%$ of BL samples, ${ }^{21}$ and most lymphomas with wild-type p53 might have lesions in other growth suppressor genes. ${ }^{22}$

"The necessary cytogenetics for the diagnosis of Burkitt's lymphoma should be the presence of the $t(8 ; 14) \quad(q 24 ; q 32)$ translocation and its variants, or c-myc rearrangement"

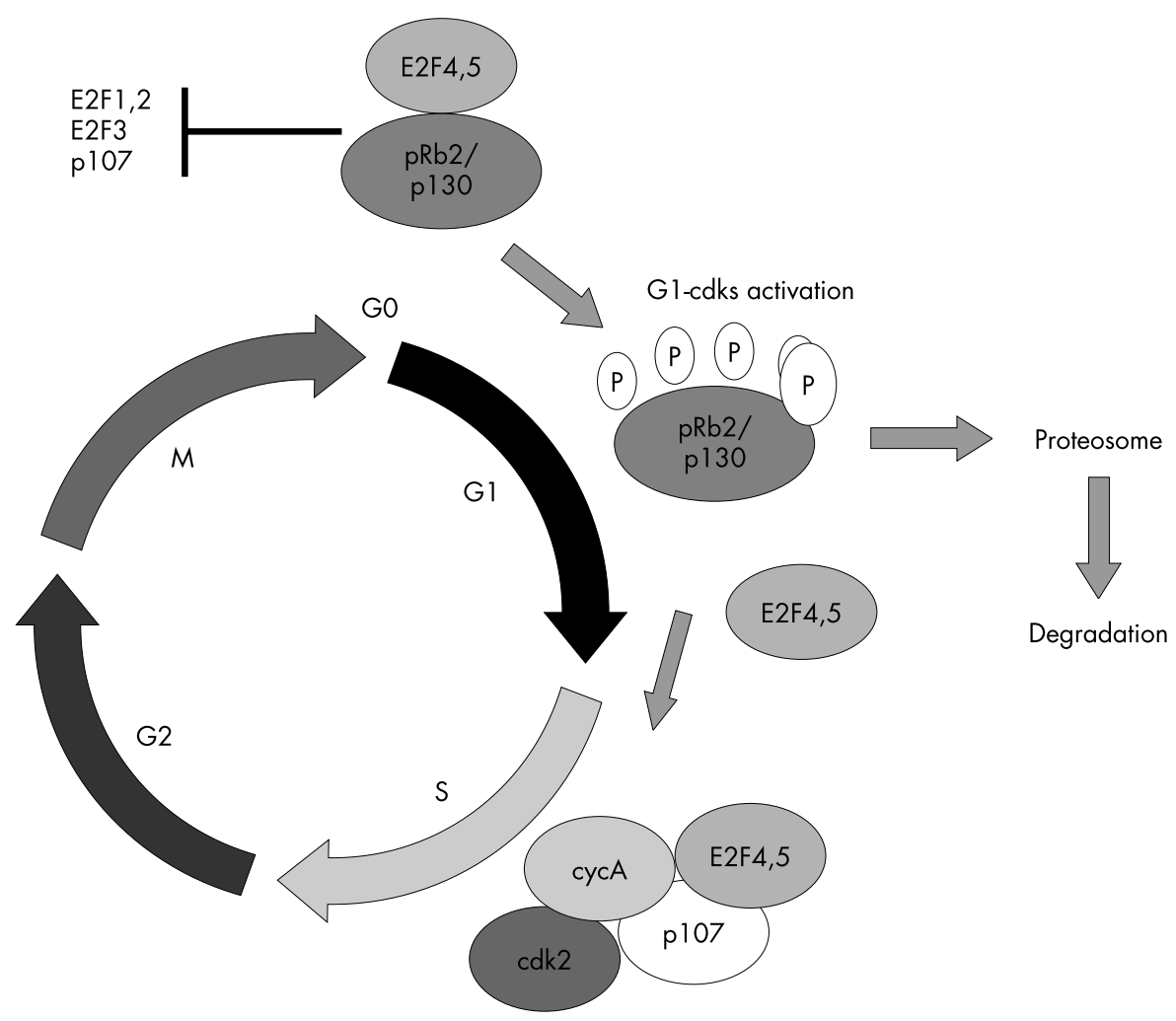

Figure 2 In quiescent $\mathrm{GO}$ cells, the nuclear $\mathrm{E} 2 \mathrm{~F}-\mathrm{pRb} 2 / \mathrm{p} 130$ complex is responsible for the active repression of several cellular promoters. After its release into the cell cycle, $\mathrm{pRb} 2 / \mathrm{pl} 30$ is phosphorylated by G1 cyclin dependent kinases (cdks) and subsequently degraded through a proteosome dependent mechanism, resulting in the derepression of a variety of genes, including $\mathrm{p} 107$. The accumulated p 107 protein is then able to interact with E2F4 and E2F5, which have been released from $\mathrm{pRb} 2 / \mathrm{p} 130$, and associate with cyclin A (cyc A)/cdk2. 
Table 2 Distribution of $\mathrm{Rb} 2 / \mathrm{p} 130$ gene mutations according to endemic, sporadic, and AIDS related Burkitt's lymphoma

\begin{tabular}{lll}
\hline & $\begin{array}{l}\text { Rb2/p130 } \\
\text { mutated }\end{array}$ & $\begin{array}{l}\text { Rb2/p130 } \\
\text { wild type }\end{array}$ \\
\hline Endemic Burkitt's lymphoma & $16 / 19$ & $3 / 19$ \\
Sporadic Burkitt's lymphoma & $6 / 13$ & $7 / 13$ \\
AIDS related Burkitt's lymphoma & $0 / 11$ & $11 / 11$ \\
\hline
\end{tabular}

Recently, mutations of the nuclear localisation signal of the $\mathrm{Rb} 2 / \mathrm{p} 130$ tumour suppressor gene have also been detected in BL cell lines and primary tumours. ${ }^{23}$ The pRb2/p130 tumour suppressor gene belongs to the retinoblastoma $(\mathrm{Rb})$ gene family, along with $\mathrm{Rb}$ and p107. Although they have similar functional properties, $\mathrm{Rb}$ family members are not functionally redundant and each protein has a different temporal profile of interaction with different E2F members. ${ }^{23-25}$ Whereas $\mathrm{Rb}$ is found in both quiescent and proliferating cells, the expression of Rb2/p130 and p107 is related to the cell cycle. ${ }^{26}$ In an ideally controlled proliferating cell population with identical cell cycle and cycle phase times, during which a given protein can be detected in the nucleus by the corresponding antibody, the percentages of cells expressing pRb2/p130 and pl07 should be inversely correlated (fig 2 ). ${ }^{27}$ Although such a pattern of Rb2/ p130 and p107 expression has been demonstrated in different types of non-Hodgkin's lymphomas, this is not the case in Bls. ${ }^{2}$

The $\mathrm{Rb} 2 / \mathrm{pl} 30$ gene is mutated in most cases of endemic BL and to a lesser extent in sporadic BL. In contrast, in AIDS related $\mathrm{BL}$, the wild-type $\mathrm{pRb} 2 / \mathrm{pl} 30$ gene is highly expressed (table 2). ${ }^{28}{ }^{29}$ In those tumours in which the Rb2/pl30 gene is mutated, the interaction between individual proteins and E2F family members and the timing of formation of particular protein-E2F complexes during the cell cycle can be deregulated (fig 3A). ${ }^{25}$ In addition to mutations of the gene, interaction with viral oncoproteins is another important mechanism of pRb2/p130 inactivation. ${ }^{3031} \mathrm{pRb} 2 / \mathrm{pl} 30$ shares, with all members of the retinoblastoma gene family, the ability to interact physically with certain DNA virus oncoproteins (fig $3 \mathrm{~B})$; by this mechanism, pRb2/p130 is inactivated yet maintained in its underphosphorylated form. ${ }^{30-34}$ Thus, the absence of mutations in the Rb2/pl30 gene and the unusually high expression of pRb2/p130 in tumours with high proliferative activity, such as AIDS related BL, may suggest a physical interaction of $\mathrm{pRb} 2 / \mathrm{pl} 30$ with viral products.

Although HIV-1 has long been recognised as the aetiological agent of AIDS, the role of HIV-1 as an oncogenic virus has not yet been well established. Data exist that clearly suggest that the HIV gene product Tat can contribute to the growth and oncogenesis of human and animal cells. ${ }^{35}$ Soluble Tat can function as a biologically active extracellular protein released by infected cells and readily taken up by uninfected cells. ${ }^{36}{ }^{37}$
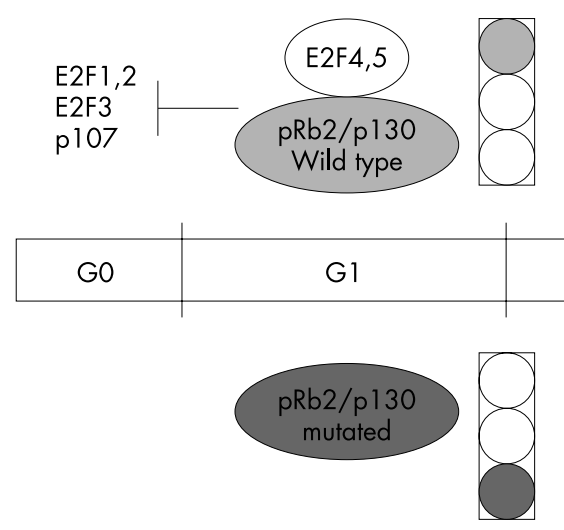

B

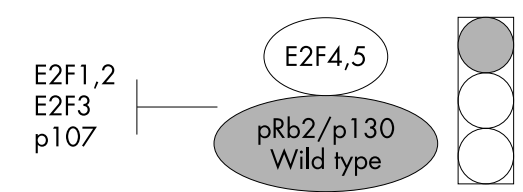

$S$

\begin{tabular}{l|l|l|}
\hline G2 & $M$
\end{tabular}

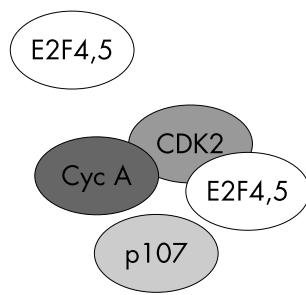

Endemic and sporadic Burkitt's lymphomas
Figure 3 (A) In the tumours where the $\mathrm{Rb} 2 / \mathrm{p} 130$ gene is mutated, the interaction between individual proteins and E2F family members and the timing of formation of particular protein-E2F complexes during the cell cycle can be deregulated. (B) pRb2/p130 shares, with all members of the retinoblastoma gene family, the ability to interact physically with certain DNA virus oncoproteins, including simian virus 40 large $T$ antigen and adenovirus $\mathrm{ElA}$ protein; by this mechanism, $\mathrm{pRb} 2 / \mathrm{p} 130$ is inactivated. CDK, cyclin dependent kinase; Cyc A, cyclin A.
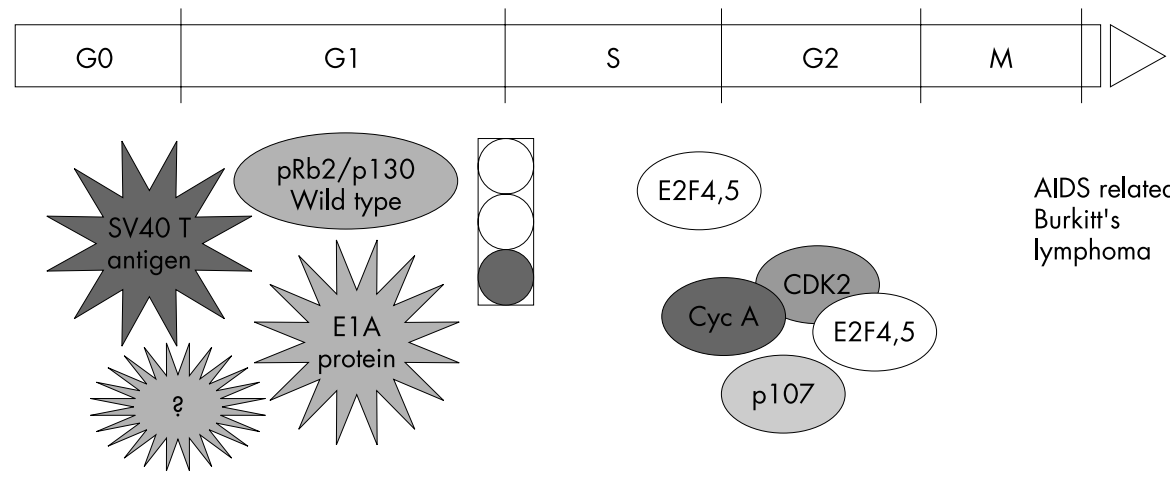

AIDS related Burkitt's lymphoma 


\section{Take home message}

- It is possible that different pathogenetic mechanisms exist among Burkitt's lymphoma subtypes

- The $\mathrm{Rb} 2 / \mathrm{p} 130$ oncosuppressor protein may be one of the targets in the interaction between human immunodeficiency virus (HIV) type 1 and host proteins

- The study of HIV associated lymphomas may provide a rich opportunity to explore aetiological interactions between HIV gene products and host cell cycle related proteins

This has also been shown to occur in AIDS related B cell lymphomas, by the diffuse and nuclear staining seen in tissue sections immunostained with anti-Tat monoclonal antibody. ${ }^{29}$ In addition, there is experimental evidence that extracellular Tat acts directly on B cells. ${ }^{38}$ In particular, germinal centre B cell proliferation was enhanced by the addition of Tat at the initiation of the culture, suggesting that Tat acts on the early stage of B cell activation, probably before the Gl to S phase transition. ${ }^{39}$ This is in line with new data indicating that the well established function of $\mathrm{Rb} 2 / \mathrm{pl} 30$ in the control of the G0/Gl transition can be inactivated by physical interaction with the Tat protein of HIV-1. In fact, the results of an in vitro and in vivo binding assay suggest that the Tat protein of HIV-1 is one of those viral oncoproteins that interact with the $\mathrm{Rb}$ family. In particular, they revealed that the Tat protein of HIV-1 interacts specifically with the pocket region of the Rb2/p130 protein. ${ }^{29}$ This can result in the inactivation of $\mathrm{Rb} 2 / \mathrm{pl} 30$ oncosuppressive properties and the induction of genes needed to proceed through the cell cycle including pl07, cyclin A, and cyclin $\mathrm{B} .{ }^{28}$ Consequently, some $\mathrm{B}$ cell clones among a virus induced B cell proliferation might have an uninterrupted cell cycle and a growth advantage, thus favouring the incidence of B cell malignancies in lymphoid organs of HIV-1 positive patients. Increased cell proliferation has been shown to account almost entirely for tumour prevalence in immunocompromised patients. ${ }^{40}$ Spontaneous regression of HIV-1 associated lymphoproliferative disorders has been reported after highly active antiretroviral therapy. ${ }^{41-43}$

"New data indicate that the well established function of $\mathrm{Rb} 2 / \mathrm{p} 130$ in the control of the G0/G1 transition can be inactivated by physical interaction with the Tat protein of human immunodeficiency virus 1"

In conclusion, our data provide evidence that different pathogenetic mechanisms may occur among BL subtypes and that the Rb2/p130 oncosuppressor protein may be one of the targets in the interaction between the HIV-l and host proteins. The study of HIV associated lymphomas may provide a rich opportunity to explore the aetiological interactions between HIV gene products and host cell cycle related proteins.

\section{Authors' affiliations}

C Bellan, S Lazzi, G De Falco, L Leoncini, Institute of Pathological Anatomy and Histology, University of Siena, Via delle Scotte, 6, 53100 Siena, Italy

A Nyongo, Department of Pathology, Nairobi Hospital, Kenya A Giordano, Sbarro Institute for Cancer Research and Molecular Medicine, Temple University, Philadelphia, PA 19122, USA

Some of the results contained in this paper have already been presented at the XI Meeting of the European Association of Haematopathology, held in Siena on 26-30 May 2002

\section{REFERENCES}

1 Burkitt DP. Sarcoma involving jaws in African children. Br J Surg $1958 ; 46: 218-23$
2 O'Conor GT. Malignant lymphoma in African children. II. A pathological entity. Cancer 1961;14:270-83

3 Tamaru J, Hummel M, Marafiotti T, et al. Burkitt's lymphomas express $\mathrm{VH}$ genes with a number of antigen-selected somatic mutations. Am J Pathol 1995;147:1398-407.

4 Isobe K, Tamaru J, Nakamura S, et al. VH gene analysis in sporadic Burkitt's lymphoma: somatic mutation and intraclonal diversity with special reference to the tumor cells involving germinal center. Leuk Lymphoma 2002;43:159-64.

5 Burkitt DP. The discovery of Burkitt's lymphoma. Cancer 1983:51:1777-86.

6 O'Conor GT, Rappaport H, Smith EB. Childhood lymphomas resembling Burkitt's tumor in the United States. Cancer 1965;18:411-17.

7 Wright DH. Burkitt's lymphoma: a review of the pathology, immunology, and possible etiologic factors. Pathol Annu 1971;6:337-63.

8 Magrath I. The pathogenesis of Burkitt's lymphoma. Adv Cancer Res 1990:55:133-270.

9 Wright D, Maclever P, Carter G. Childhood non-Hodgkin's in the United Kingdom: findings from the UK children's cancer study group. J Clin Pathol 1997;50:128-34

10 Pellicci PG, Knowles DM, Magrath I, et al. Chromosomal breakpoints and structural alteration of the c-myc locus differ in endemic and sporadic forms of Burkitt's lymphoma. Proc Natl Acad Sci U S A 1986;83:2984-8

11 Shiramizu B, Barriga F, Neequaye J, et al. Patterns of chromosomal breakpoint location on Burkitt's lymphoma: relevance to geography and Epstein-Barr association. Blood 1991;77:1516-26.

12 Lazzi S, Ferrari F, Nyong'o A, et al. HIV-associated malignant lymphomas in Kenya (equatorial Africa). Hum Pathol 1998;29:1285-9.

13 Carbone A, Gloghini A, Gaidano G, et al. AIDS-related Burkitt's lymphoma: morphologic and immunophenotypic study of biopsy specimens. Am J Clin Pathol 1995; 103:561-7.

14 Pathology and genetics: tumors of haematopoietic and lymphoid tissues. The World Health Organisation classification of tumors. Jaffe ES Harris NL, Stein $\mathrm{H}$, et al, eds. Lyon: IARC Press, 2001.

15 Subar M, Neri A, Inghirami G, et al. Frequent c-myc oncogene activation and infrequent presence of Epstein-Barr virus genome in AIDS-associated lymphoma. Blood 1988;72:667-71.

16 Harris NL, Jaffe ES, Stein $\mathrm{H}$, et al. A revised European-American classification of lymphoid neoplasms: a proposal from the international lymphoma study group. Blood 1994;84:1361-92

17 Braziel RM, Arber DA, Slovak ML, et al. The Burkitt-like lymphomas: a southwest oncology group study delineating phenotypic, genotypic, and clinical features. Blood 2001:97:3713-20.

18 Gaulard Ph, Delsol G, Callat MP, et al. Cytogenetic and clinicopathologic features of B-cell lymphomas associated with the Burkit translocation $\mathrm{t}(8 ; 14)$ (q24; $\mathrm{q} 32$ ) or its variants. J Clin Pathol 2002; 55(suppl 1):A22.

19 Peukert K, Staller P, Schneider A, et al. An alternative pathway for gene regulation by myc. EMBO J 1997; 16:5672-86

20 Hangaishi A, Ogawa S, Imamura N, et al. Inactivation of multiple tumor-suppressor genes involved in negative regulation of the cell cycle, $\mathrm{MTS} 1 / \mathrm{p} 16^{\mathrm{INK} 4 \mathrm{~A}} / \mathrm{CDKN} 2, \mathrm{MTS}_{2} / \mathrm{p} 15^{\mathrm{INK} 4 \mathrm{~B}}, \mathrm{p} 53$ and Rb genes in primary lymphoid malignancies. Blood 1996;87:4949-58.

21 Preudhomme C, Dervite I, Wattel E. Clinical significance of p53 mutation in newly diagnosed Burkitt's lymphoma and acute lymphoblastic leukemia: a report of 48 cases. J Clin Oncol 1995;13:812-20.

22 Bhaitia K, Fan S, Spangler G, et al. A mutant 21 cyclin-dependent kinase inhibitor from a Burkitt's lymphoma. Cancer Res 1995:55:1431-5.

23 Cinti C, Claudio PP, Howard CM, et al. Genetic alterations disrupting the nuclear localization of the retinoblastoma related gene RB2/p130 in human cell lines and primary tumors. Cancer Res 2000;60:383-9.

24 Claudio PP, Howard CM, Baldi A, et al. p130/pRb2 has growth suppressive properties similar to yet distinctive from those of retinoblastoma family members $\mathrm{pRb}$ and $\mathrm{p} 107$. Cancer Res 1994;54:5556-60

25 Vairo G, Livingston DM, Ginsberg D. Functional interaction between E2F-4 and p130: evidence for distinct mechanisms underlying growth suppression by different retinoblastoma protein family members. Genes Dev 1995;9:869-81

26 Hurford RK, Cobrinik D, Lee MH, et al. pRb and p107/p130 are required for the regulated expression of different sets of $E 2 F$ responsive genes. Genes Dev 1997;11:1447-63.

27 Leoncini L, Bellan C, Cossu A, et al. Retinoblastoma-related p107 and $\mathrm{pRb} 2 / \mathrm{p} 130$ proteins in malignant lymphomas: distinct mechanisms of cell growth control. Clin Cancer Res 1999;5:4065-72.

28 Cinti C, Leoncini L, Nyongo A, et al. Genetic alterations of the retinoblastoma related gene RB2/p130 identify different pathogenetic mechanisms in and among Burkitt's lymphoma subtypes. Am J Pathol 2000;156:751-60.

29 Lazzi S, Bellan C, De Falco G, et al. Expression of RB2/p130 tumor suppressor gene in AIDS-related non-Hodgkin's lymphomas. Implications for disease pathogenesis. Hum Pathol [In press.]

30 Del Valle L, Baehring J, Lorenzana C, et al. Expression of a human polyomavirus oncoprotein and tumour suppressor proteins in medulloblastomas. Mol Pathol 2001;54:331-7.

31 Stubdal $\mathbf{H}$, Zalvide J, De Caprio JA. Simian virus 40 large T antigen alters the phosphorylation state of the RB-related proteins p130 and p107. J Virol 1996;70:2781-8.

32 De Luca, Baldi A, Esposito V, et al. The retinoblastoma gene family $\mathrm{pRb} / \mathrm{p} 105, \mathrm{p} 107, \mathrm{pRb} 2 / \mathrm{p} 130$ and simian virus-40 large T antigen in human mesothelioma. Nat Med 1997;3:913-16. 
33 Desiardins $\mathbf{P}$, Pilon AA, Hassell JA, et al. Polyomavirus large T-antigen binds the "pRb related" protein p130 through sequences in conserved region 2. Virus Res 1997;47:85-90.

34 Zalvide J, De Caprio JA. Role of pRb-related proteins in simian virus 40 large-T-antigen-mediated transformation. Mol Cell Biol 1995:15:5800-10

35 Altavilla G, Trabanelli C, Merlin M, et al. Morphological, histochemical immunohistochemical, and ultrastructural characterization of tumors and dysplastic and non-neoplastic lesions arising in BK virus/Tat transgenic mice. Am J Pathol 1999;154:1231-44.

36 Rubartelli A, Poggi A, Sitia R, et al. HIV-1 Tat: a polypeptide for all seasons. Immunol Today 1998; 19:543-5

37 Prakash O, Tang ZY, He Y, et al. Human Kaposi's sarcoma cell-mediated tumorigenesis in human immunodeficiency virus type $1 \mathrm{Ta}$ -expressing transgenic mice. J Natl Cancer Inst 2000;92:721-8.

38 Huang L, Li CJ, Pardee AB. Human immunodeficiency virus type 1 TAT protein activates B lymphocytes. Biochem Biophys Res Commun 1997;237:461-7.
39 Lefevre EA, Krzysiek R, Erwann PL, et al. Cutting edge: HIV-1 protein differentially modulates the $B$ cell response of naive, memory, and germinal center B cells. J Immunol 1999;163:1119-22.

40 Ellwein LB, Purtillo DT. Cellular proliferation and genetic events involved in the genesis of Burkitt's lymphoma (BL) in immune compromised patients. Cancer Genet Cytogenet 1992;64:42-8.

41 Chow KU, Mitrou PS, Geduldig K, et al. Changing incidence and survival in patients with AIDS-related non-Hodgkin's lymphomas in the era of highly active antiretroviral therapy (HAART). Leuk Lymphoma 2001;41:105-16.

42 Kirk O Pedersen C, Cozzi-Lepri A, et al. Non-Hodgkin lymphoma in $\mathrm{HIV}$-infected patients in the era of highly active antiretroviral therapy. Blood 2001;98:3406-12

43 Sarkodee-Adoo C, Pittarelli L, Jaffe E, et al. Regression and clonally distinct recurrence of immunodeficiency virus related Burkitt-like lymphoma during antiretroviral therapy. Leuk Lymphoma 2001;42:1125-31

Troponin $\mathrm{T}$ better than standard enzymes for estimating extent of myocardial infarct

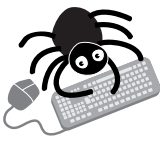

Please visit the Journal of Clinical Pathology website [www. jclinpath.com] for link to this full article.
$\mathrm{O}$ ne measurement of the protein troponin $\mathrm{T} 72$ hours after the start of chest pain is better than using standard enzyme tests to estimate the extent of tissue damage following heart attack, concludes German research.

Creatine kinase, $\mathrm{CK}-\mathrm{MB}$, and lactate dehydrogenase require serial sampling to identify peak or cumulative serum concentrations and depend on coronary reperfusion. Furthermore, these enzymes are not exclusive to the myocardium and increases could indicate causes other than myocardial cell damage.

Enzyme activities and serum troponin T were measured after the start of chest pain in 37 patients with a first time heart attack. Blood samples were drawn every four hours on day 1 , every eight hours on days 2 and 3, and then once daily until day 10. All but 14 (group 1) had early coronary reperfusion (group 2). Quantitative single photon emission computed tomography thallium-201 scintigraphy was performed at rest two to three weeks after symptoms had begun.

Troponin T concentrations peaked briefly within the first 24 hours, and then again on days 3 to 4 in both groups. The extent of irreversible myocardial damage, indicated by scintigraphy, was accurately reflected in troponin $\mathrm{T}$ concentrations taken 72 hours after the start of symptoms in both groups.

The authors conclude that a single measurement of troponin T, taken 72 hours after the start of chest pain, is simple, reliable, and better than enzyme methods.

Heart 2002:87:520-524. 